\title{
Exploration and Practical Study on the Blended Teaching Model of College English
}

\author{
Yani Zong \\ Xi’an International University, Xi'an, Shaanxi, 710077
}

Keywords: Blended Teaching Model, College English, Practical Study.

\begin{abstract}
With the development of economic globalization, China has increasingly paid attention to economic and commercial communication than before, so the teaching of foreign language has been taken seriously in China. English, as a widely used language in the world, efficiency of the English teaching also has been highlighted in China's teaching system. The blended teaching model of college English has changed the traditional teaching situation by which students are filled with the knowledge passively, and it also has better shown the function of teacher's guidance and assistance. It can help students fulfill their goals, which are independent and lifelong learning. Therefore, the exploration and practical study on the blended teaching model are of great significance.
\end{abstract}

\section{Introduction}

The Internet and other technologies have changed our life and study a lot; they let us carry out some activities freely without the limitations such as time, space and geographical location. College English is a compulsory course in many colleges and universities, its teaching and learning models are both influenced by modern technologies. The teaching of college English requires both face- toface teaching between the teachers and students and watching the English videos and finding some relevant English teaching materials, which can enrich the teaching contents. At the some time, students also can have the diversified ways to acquire knowledge. What's more, the teaching model of college English also needs to be reformed by the modern technologies, and needs to change the formal teaching model and the "Mute English" phenomena, i.e. teachers should not only let students know the meaning of the words and sentences, but also allow students express themselves freely and exactly so as to encourage the students' enthusiasms and interests on English learning.

\section{Blended Teaching Model}

Blended teaching means teachers combine advantages of traditional teaching models with modern Internet and other digital technologies to make the best of teachers' functions such as inspiration, supervision, and guidance, and to inspire the creativity and initiative of the student ${ }^{[1]}$. Compared with traditional teaching models, the blended teaching is a kind of reformation and innovation to some extent, it improves the traditional thought of teaching and studying, and the teaching efficiency as well. It also can improve teaching efficiency and help students a lot on mastering professional knowledge and improving their overall qualities by the correct use of this teaching model. In addition, the blended teaching changes the traditional structure of teachers and students, can get teaching contents much better analyzed, and makes it possible to reasonably control the rhythm of the class. In this way efficient teaching efficiency will be ensured.

Applying the blended teaching model to college English teaching fully shows the students' autonomy on their study, their personalized development and teachers' teaching model of inspiration and guidance. A key factor that blended teaching model involves is the idea of lifelong studying which guides the students to constantly learn by themselves in their daily life, and to study pertinently according to their different individual conditions. So this teaching model is very helpful to language learning such as English. It is necessary to consider individual differences of the students, and develop appropriate methods for their independent learning so as to help students to 
find , explore and solve problems. The proper guidance from the teachers in class could have a great influence on students' learning after class, and teachers can help students to think about their problems while solving students' learning difficulties, and then, it can reduce the difficulties of students' learning ${ }^{[2]}$. Based on this, blended teaching model has the features of guidance, self-learning and lifelong learning.

\section{Analysis on Current College English Teaching Situation}

For many colleges, English is one of the compulsory courses; most of its teaching models is face- to- face teaching that has specific and unified teaching goals. In this model, teachers teach students face to face in a certain room according to the special teaching plans which follows the teaching goals. This kind of teaching model shows a lively scene in which a teacher is teaching knowledge on the platform while students are listening to their teacher carefully and taking some notes about some key points. The other lively scene is that students just follow their teachers' thoughts passively without enough thinking by themselves, they only can acquire and master the new knowledge by the means of following the teacher's order to discuss, to finish exercises, or to recall the notes that they have taken in class. On the contrary, teachers constantly introduce new knowledge to students in class and check students' homework or assignments so as to know the studying situation of the students. This kind of traditional teaching model is very common in current college, and is the most important means of teaching. To sum up, the traditional teaching model has these defects as follows: first of all, it carries out teaching activities in a simple and rigid way, it is difficult for students to master English either in listening, speaking or reading and writing as a type of comprehensive knowledge; then, the dominant position of students has not been fully reflected, students still learn English in a passive way, it is difficult to inspire the students' subjectivity and creativity; finally, by the strong restrictions of time, space and location, students' time distributions of studying and their learning models are lack of flexibility ${ }^{[3]}$.

\section{Exploration and Practical Study of the College English Blended Teaching Model.}

The blended teaching model of college English, which this thesis explores, is based on the conception of blended teaching model first, and then it supposes the modern Internet and computer technologies as the framework, at last, combines the traditional face- to- face teaching model with the current popular Internet video studying model, so as to discuss how to integrate the English teaching with English listening, speaking, reading, writing and translating.

In the first part of the thesis, one of the essential factors of blended teaching model we induced is the inspiring function from the teachers which could promote the students to study by themselves and study all their lives. So, the blended teaching model of college English not only requires using the advantages of traditional teaching model, but also the advantages of the Internet and computer technologies so as to change the learning conditions, and then the students could join English learning heart and soul ${ }^{[4]}$. Teachers should not only introduce new knowledge to students all the time, but also help students to solve their problems, guide students to learn new knowledge, and supervise students' studying conditions. The writer of the thesis explores the blended teaching model of college English as below:

First, make the best use of class teaching. Although the blended teaching model of college English requires making the best use of Internet and computer technology, but it doesn't mean abandoning the class teaching, but to use the every minute efficiently in class. Teachers should compare and analyze the key points of knowledge, and answer the questions and the key points during the students' independent studying.

Second, make the best use of teachers' guidance. The obvious difference between the blended teaching model and the traditional teaching model is that teachers' face -to -face teaching exists in different teaching stages of the two models. College English teachers should make the best use of the advantages of guiding the students to study by themselves, in order to promote students to prepare lessons before class and review the knowledge after class independently. In addition, 
teachers also could teach some correct studying methods and some reasonable studying ideas to the students based on individual differences, so as to let the students have a right understanding about English learning, i.e. it not only aims at getting the relevant certificates such as CET4, CET6, diploma certificate, degree certificate etc, but also students can communicate with others freely in daily work and life, and have strong competitiveness in their career life.

At last, strong studying interests of the students. The blended teaching model requires teachers to guide students study online, to help students to bring up the interest of English learning and take part in the extracurricular activities actively, to understand, master the knowledge and to promote their independent study abilities, so as to improve the students' learning efficiency, their English expressive abilities and applied abilities.

Online studying of the blended teaching model means students use the current online studying platform to study such as Weibo, Wechat, and QQ. During online study, students could exchange their ideas and experiences, and share studying resources; they also can consult their teachers about the problems they can not understand, and fulfill the homework their teachers have given to them online ${ }^{[5]}$.

The blended teaching model of college English mainly combine the advantages of the traditional teaching model and the advantages of online studying, it requires different learning contents during the different learning stage, and different learning methods. The thesis introduces it as below:

(1) Before face -to -face teaching. Teachers could assign tasks to students via online studying platforms, and supervise students' studying; students could prepare lessons by reading textbooks, consulting relevant materials online or other learning ways. Then, they could discuss and share their learning experiences online so as to make the best use of online studying platform.

(2) During the face to face teaching. Face- to -face teaching stage is the main studying stage. Teachers should fully understand and sort the teaching contents, and teach the key and difficult points to students carefully. During teaching, teachers should bring out questions about a certain issue, and guide students to analyze and solve the questions, and then demonstrate the solving conditions about the questions. At the same time, teachers should give an overall and comprehensive review of the results of their students, point out the existing problems, and help them to correct their problems and enrich their experiences on solving problems. Teachers also should record the daily studying records and combine this with the examination records after the semester in order to promote the students to actively join class activities.

(3) After face- to -face teaching. The blended studying model after face -to- face teaching aims at checking and consolidating the studying achievements that the students have achieved in the previous two stages, so as to ensure the quality of the study. Subjects about language are more practical, and English learning requires students to communicate with others freely in English and have the better abilities of watching, listening, speaking, reading, writing, and translating, so, it is feasible to adopt the various English activities to consolidate the learning achievement, such as English speech, short act.

\section{Practical rethinking on the blended teaching model of college English.}

The blended teaching model of college English brings the new thinking and methods to college English teaching, it improves students' independent learning abilities, at the same time, it increases the advantages of modern technologies and the traditional teaching model, it allows the English learning resources to be used totally, and lets we rethink the innovation and reform of the traditional teaching model ${ }^{[6]}$. When teachers practice the blended teaching model, they could take students as the principal part, the model clarifies the tutorial role of the teacher, and fully shows the guiding value of the teachers. What's more, the blended teaching model explores more enough spaces to the students for their studying, and promotes the preparation activities and the activities for the students to consolidate new knowledge they have learned. During the application of the blended teaching model, all the teaching activities requires lots of language recourses, teachers should design a set of class activities that fit the students' realistic abilities and the future development of the students, so as to improve the reading, writing, expressive and practical applied abilities of English. In the 
current teaching reform, the teaching activities show the features of variety and pluralism; these challenge the teachers a lot on fulfilling their teaching task excellently. How to let the teachers and students play an appropriate role in class and how to supervise the studying achievements of the students are the key points during the research and application of the blended teaching model.

\section{References}

[1]Wang Hongli. Exploration on the Blended Teaching Model of Academic English[J]. Journal of Shanghai Second Polytechnic University, 2017,01:68-71.

[2]Yang Fang, Wei Xing, Zhang Wenxia. Exploration and Research on the Blended Teaching Model of College English Teaching[J]. Computer-Assistant Foreign Language Education, 2017,01:21-28.

[3]Li Ying. Exploratory Research on the Blended Teaching Model of College English Teaching[J]. Journal of Bohai University(Philosophy \& Social Science Edition), 2016,06:114-117.

[4]Wang Chunni. Applied Research on the Blended Teaching Model of the college English Teaching[J]. Spiritual Leaders, 2016,17:71.

[5]Zhang Mingyong. Try To Discuss on the Construction of the Blended Teaching Model of College English[J]. Journal of Wuhan Metallurgical Manager's Institute, 2015,02:71-73.

[6]Zhang Yi, Gao Jian. Applied Research on the Blended Teaching Model of College English----Take a Research of Our College For Example. The Chinese Journal of ICT in Education, 2015,18:55-58+87. 